\title{
The technical-industrial research institutes in the Norwegian innovation system
}

Lars Nerdrum and Magnus Gulbrandsen

NIFU STEP, Oslo.

Correspondence: magnus.gulbrandsen@nifustep.no

\begin{abstract}
This paper analyses the role of technical-industrial research institutes for industrial innovation in Norway. Using statistical data and a survey among firms, the paper shows that there are many different types of interaction between institutes and firms. In addition to R\&D and technical services, the institutes are a significant source of skilled manpower for firms. We highlight three central roles for the institutes: they are a learning partner for industry, they help increase absorptive capacity, and they constitute a flexible repository in the innovation system by helping firms in peak periods and by reducing the pressure on universities through assisting in teaching and supervision.
\end{abstract}

Version of 8.8.2007

TIK Working paper on Innovation Studies No. 20070614

*This paper is part of the project "Innovation, Path-dependency and Policy" (IPP) carried out at the Centre for Technology, Innovation Culture (TIK), University of Oslo with the support of the Norwegian Research Council (Contract no. 154877). However, the Centre, University and Research Council are not responsible for the content of the paper, which is the sole responsibility of the author(s). 


\section{Introduction}

In developed countries publicly supported research is most often organised in two types of organisations; the higher education system and public/non-profit research institutes, often defined as such because they do not formally offer higher education or teaching activities. The place devoted to organisations with little or no teaching varies greatly between countries. Neighbours Norway and Sweden represent two opposite models for public research. In Norway, research institutes constitute an integrated part of the public research system, and interact closely both with universities and with firms and other actors (Gulbrandsen and Nerdrum 2007b). Many institutes (within meteorology, veterinary medicine, geology and marine research, for instance) were well established already in the early part of the last century, and the post world war II period witnessed the emergence of many new institutes with a variety of users and orientations (Gulbrandsen and Nerdrum 2007a). In Sweden, in contrast, there are only few and small publicly funded research institutes outside of the higher education system. Recently, the size of the Norwegian institute sector has been highlighted as a problem and it has been suggested that it may be a burden rather than a resource for firm level of innovation (Arnold et al. 2001). But is this assessment really based on solid evidence? Our aim in this paper is to characterise the research institutes in Norway and to explore their relationship to other actors in Norway. In particular we will examine the services supplied by the technical-industrial research institutes to firms and business in Norway and the importance of the former to the latter. 


\section{Challenging the usefulness of research institutes}

Industry- and mission-oriented research institutes are not very visible in contemporary theories of innovation and knowledge production. In recent years many such laboratories have been reduced in size or abandoned because they have been regarded as institutionalisations of the much criticized "linear" model of innovation (seeing innovations as spin-offs from basic research) or reflections of failed "national champions" policies (supporting specific firms in sectors of alleged "strategic" importance). For these reasons, the sector has been under strain for several decades all over the Western world. Nevertheless, In many countries, the public laboratories have emerged strengthened from these policy discussions, not least due to the need for independent expertise in society (Larédo and Mustar 2001). The institutes may still be caught between the public and private sector, between "market nihilism" and "academic nostalgia” as Mathisen (1989) puts it, but they carry out an extremely wide range of activities (Larédo 2003). Thus, public laboratories or research institutes are still relevant actors in the national innovation system in many countries (Crow and Bozeman, 1987; Nelson 1993; Nelson and Rosenberg 1993; Larédo and Mustar 2001; Larédo 2003, Ministry of Education and Research 2005). It is nevertheless important to underline the very different organisational forms and orientations of research institutes in otherwise similar countries. In one of rather few international comparisons Slipersæter et al. (2003) find that country specificities and the roles taken on by research organisations of this type differ much across countries, and that it is rather difficult to compare them directly. The data we use here is rather unique and cannot be readily compared with other data sources in other countries or provided by international organisations. 
The role of the Norwegian research institutes was questioned in a large evaluation of the Research Council of Norway (RCN). Using a national innovation system perspective, the evaluators asserted that the relative size of the research institute sector was problematic, and they stated that there is "an enormous imbalance in the respective sizes of the institute and university sectors” (Arnold et al. 2001, p. 29). Three possible problems were identified as consequences of the size of the research institute sector:

- “absorptive capacity” (Cohen and Levinthal 1989) of industry could be weakened because valuable trained researchers work in research institutes rather than in industry,

- $\quad$ institutes may prevent a modernisation of the university system by contributing to locking in universities in an old-fashioned basic research paradigm,

- potential benefits from applied research activities on higher education activities could fail because the higher education system operates sub-optimally: much R\&D is conducted in research institutes and the higher education sector becomes too lean and fails to reach critical mass.

None of these assertions were established empirically by the evaluators, rather they called for more research to validate hypotheses concerning potential problems of research institutes in a national innovation system like the Norwegian. This paper will provide some evidence to address some of these issues.

\section{The size and profile of the institute sector in Norway}

R\&D statistics and the general guidelines for basic funding made by the Research Council of Norway (RCN) may yield an impression that the institutes constitute a homogeneous sector but the reality is much more complex. Research institutes in Norway are “...a highly 
heterogeneous collection of units with different tasks and target groups, different background, different financial basis, and different organisational and affiliation forms” (Ministry of Education and Research 2005. p. 169). Among the technical-industrial institutes, which constitute the principal focus here, there are some clearly "mission-oriented" ones such as the Norwegian Defence Research Establishment and the Institute for Energy Technology (previously named the Institute for Atomic Energy). Other, like SINTEF, are clearly useroriented, while some, such many of the agricultural and environmental institutes, serve both purposes. Some of the user-oriented institutes also function in symbiosis with a higher education organisation; SINTEF and NTNU are a clear example of that.

Measured by expenditure the research institutes produce around one-quarter of the national R\&D. This is only slightly less than the higher education system (Research Council of Norway 2006). Comparing the Norwegian research institutes to those in other countries, Slipersæter et al. (2003) found that although the share of total R\&D expenditures spent in research institutes in Norway is relatively high (23 percent), the share of public spending of $R \& D$ in the institutes is relatively low (61 percent). A recent examination of framework conditions for research institutes found that Norwegian institutes receive less funding from public research programmes than institutes in Denmark, Sweden, the Netherlands and Germany, but around the same as Finnish institutes (Brofoss and Slipersæter 2004). As far as the so-called "technical industrial research institutes” (see below) are concerned, public basic grants only account for around 8 percent of their incomes. In addition to basic grants, RCN awards "strategic institute programmes" so that general public funding constitute around 13 percent of the institutes' incomes. The remaining incomes are generated from projects and R\&D services provided to national and foreign customers. 
An important contributor to the Norwegian policy of industrial R\&D was the Green Paper of the Thulin Commission from 1981 (NOU 1981, Gulbrandsen and Nerdrum 2007a). According to Wiig and Mathisen (1994), this report first formulated the "double purpose policy" of these technical-industrial research institutes, which has been an important leitmotiv to the industrial research institutes in Norway since then. The double purpose policy has two facets. First, industrial institutes should constitute an R\&D infrastructure to which firms can turn with their needs for competence, knowledge and R\&D equipment that it is neither desirable nor economically possible for most firms to acquire and maintain in-house. Second, institutes should serve as "intermediators" between firms and universities. Technical needs of firms should be interpreted, translated and transferred to university researchers to give them an idea of technological usefulness and to inspire new research and to provide an impetus to direct research activities into industrially relevant areas. A central premise for the Thulin commission was that Norway has an unusually large number of small and medium-sized enterprises in industries which are not very $R \& D$ intensive. Their needs for new knowledge, technology and problem solving are therefore best met by publicly subsidised organisations with an explicit goal to contribute to a prosperous Norwegian industry. Practically oriented institutes with linkages to the research frontier and graduate production were seen as important in reducing problems of weak absorptive capacity in industry.

This “double purpose policy” has been applied at technical-industrial research institutes since the Thulin Commission, but recently arguments of learning and capacity building have increasingly received more attention. According to the recent White Paper (Ministry of Education and Research 2005; pp. 172-173) this new emphasis on learning may constitute a more explicit mission for the institute sector within the context of the wider educational system (through doctoral training and supervision). A new funding system for the institutes 
which is currently being developed (Norges forskningsråd 2006) proposes incentives both for “quality” (e.g., doctoral training and publishing) and (user) relevance, reemphasising the “dual role” for the sector.

It is not clear from the available data sources how many firms purchase services from the institutes and for how much money. A comparison of different sources was made by Brofoss et al. 2002, using data sources from 1999 and 2000. According to the industrial R\&D statistics, less than 500 companies purchased R\&D services from the institutes in 1999 for a total of 672 million NOK. These figures do not contain companies with less than 10 employees and only a selection of those with between 10 and 50 employees. Data covering industrial contracts of 41 institutes from 2000 showed that around 1,400 firms purchased services from these institutes for around 990 million NOK (Broch et al. 2001). These figures exclude projects less than 10,000 NOK (of which there are many) and projects where the company name could not be identified. However, many of these projects would probably not be classified as R\&D according to the definitions of the Frascati manual. Data from the Research Council from 2000 showed that around 1,500 firms were involved in "usercontrolled research programmes”, and the institutes themselves reported that firms purchased services for around 1,450 million NOK this year. Finally, newer data from the R\&D tax deduction scheme SkatteFUNN (see www.skattefunn.no) show that more than 6,000 companies were involved in projects approved for R\&D tax deduction in the years 20022005. Around 30 percent of these involved collaboration with public R\&D organisations. Of around 1,500 active collaboration projects in 2005, 413 involved collaboration with the research institute SINTEF while 131 used the technical university NTNU as a partner, indicating a high degree of involvement by the two major industrially oriented research organisations in the Trondheim area. Thus, the institutes have a large number of industrial 
customers but not all contracts are strictly related to R\&D. We will return to some of these data sources below in our more detailed exploration of the role of the research institutes in the innovation system.

\section{[FIGURE 1 ABOUT HERE]}

The 110 organisations which belong to the Norwegian institute sector vary greatly in size, ownership, location, organisational status, field of research, working conditions and research orientation (Slipersæter et al. 2003). The distribution according to field of research is shown in Figure 1. These organisations have been established at various periods of time, always with the aim that the establishment would respond to needs for applied knowledge in public administration or industry (cf. Gulbrandsen and Nerdrum 2007a; Skoie 2005). For instance, different ministries established quasi-dependant research institutes to respond to their needs for facts, insight and research activity in particular fields. In the remainder of this paper we will focus on what in Norway is known as "technical-industrial research institutes”, i.e. organisations which have industry collaboration and contract research explicitly as main tasks. This is the largest sub-field of the institute sector in terms of volume of performed R\&D in Norway (cf. Figure 1).

\section{Services, activities and customers of R\&D institutes in Norway}

In order to shed light into the effects of $R \& D$ in research institutes for industrial research, we conducted a survey among firms in 2002. Statistics Norway drew a sample of firms from the 
business register for the 30 most R\&D-intensive two-digit NACE industries. Although firms of all sizes were selected the sampling method favours large firms. After removing a number of firms which were not relevant to the survey, we ended up with a sample of 986 firms. After one reminder we finally received a response from 460 firms, or a response rate of around 47 percent. Unfortunately we had to send the reminder anonymously which gave us very limited possibilities for researching into dimensions such as size, geography and industrial affiliation. The survey is documented more in detail by Brofoss and Nerdrum (2002).

Of the 460 firms responding to the survey, around one-third reported that they had purchased $R \& D$ from external suppliers in 2000. Among the firms which reported in-house $R \& D$, the share which had bought R\&D from external suppliers was 87 percent. This indicates that inhouse R\&D and purchased R\&D to a large extent are complements, a finding largely consistent with Cohen and Levinthal (1989). 13 percent of the firms reported having bought R\&D services from other firms within the same establishment. In terms of cost, these types of purchases are also the most important. However, nearly 22 percent of the firms had purchased R\&D services from research institutes in Norway, while only around 7 percent of the firms had purchased R\&D services from universities or colleges. This suggests that research institutes is a more widely used source of $R \& D$ for firms than the higher education system for this sample of firms, which are chosen among the most R\&D intensive ones in Norway. Brofoss and Nerdrum (2002) compared the shares and figures from the survey with R\&D statistics from Statistics Norway and suggested that the imbalance found (more purchases from research institutes to firms in the survey than in the $R \& D$ statistics) was due to a stricter definition of R\&D (Frascati definition) in the R\&D statistics than by firm representatives when asked directly. As definitions of R\&D may vary according to criteria connected to schemes of public support, this becomes an important issue. Many of the services provided by 
the research institutes - like testing, consultative services, training - are provided by researchers or people who spend considerable shares of their working time on R\&D activities. The nature and qualities of these services can therefore be considered as R\&D outcomes in the sense that they might have been difficult to provide without the R\&D skills and orientation towards $R \& D$ by the staff and $R \& D$ organisations producing them.

\section{Industrial projects in research institutes}

Brofoss and Nerdrum (2002) show that the most important type of services firms purchased from research institutes were directed at product development, while process development comes next. But also testing and consultancy services were important to many firms. In Table 1 we distinguish between four types of institutes - primary sector institutes, social sciences, “environment and development” and "science and technology” - following the classification used by the Research Council of Norway.

Many institutes have a large number of company-paid projects of less than NOK 10,000 $(€ 1,250)$ which are not included in Table 1 . These are frequently called “training”, “upgrading”, “teaching”, “seminar” etc., indicating that the institutes constitute an arena for learning and keeping in touch with scientific and technological developments for the firms. Even when removing these very small contracts, less than half of the remaining portfolio consists of projects greater than NOK 100,000 (EUR 12,500). The "environment and development” institutes have a particularly high share of small projects (see Figure 2), probably related to various test services (pollution, chemical composition of materials etc.). If we expect R\&D projects to be somewhat complex and long-term, this clearly indicates that 
more than half of the institutes’ projects are probably not R\&D in a strict definition of the term. The data material does not allow us to say whether the activities within tiny projects are based on $R \& D$ or not - if they e.g. are related to the largest projects and/or other types of funding. The numbers also show the tremendous administrative challenges for many institutes, handling large numbers of projects which still constitute a small share of their turnover. However, for the sample as a whole, the largest projects $(>€ 125,000)$ constitute around half their turnover, indicating the dependence of many institutes of a relatively small number of customers and projects.

[TABLE 1 ABOUT HERE]

[FIGURE 2 ABOUT HERE]

\section{Why firms purchase R\&D services from research institutes}

In the following we will investigate more in detail the issue of motivation among firms to contract R\&D from research institutes using data from the firm-level survey undertaken by Brofoss and Nerdrum (2002). Factor analysis is a statistical method used to understand response patterns. It enables us to see how the responses co-relate so that one can identify groups of respondents who tend to respond in the same way when confronted to many different questions. The method identifies responses which co-vary and allows different "factors" to be extracted from the data. The issues (questions) underpinning these factors show what kind of response patterns we have, and we label these factors in accordance with the weight ("loadings") of these issues (questions) on the various factors. We used principal 
components as extraction mechanism, eigenvalue above one as selection method and Varimax rotation with Kaiser normalization. The analysis was undertaken using SPSS 15.

\section{[TABLE 2 ABOUT HERE]}

In 0 we show a factor analysis computed from the responses to questions about why the firms purchase R\&D services from Norwegian research institutes. We find that the firms use institutes for four different types of reasons. We call the first type $R \& D$ motivation, which seems the major driving force of a group of firms’ R\&D purchases. Many firms find the inhouse $R \& D$ knowledge insufficient, and their purchases of $R \& D$ services from research institutes constitute a conscious strategy of increasing the firm's R\&D competencies and quality as well as a motive to join competence networks. This cluster of reasons was emphasized by between half and two-thirds of the respondents.

The second type of motive is labelled Accessible; these firms state that they lack their own equipment or test facilities, they stress geographical proximity and personal contacts, and they agree that they only know (some) Norwegian institutes. A closer look at the dataset tells us that these firms are primarily situated in and around the Trondheim area, where SINTEF and other important research institutes are located. It is interesting that firms from this area perceive their proximity to these research institutes an advantage, but at the same time, that firms in regions without institutes do not consider distance as a serious problem for collaboration. Possible explanations to this geographically determined response pattern may be that the firms in the Trondheim area have access to a more complete knowledge base in the 
local research infrastructure than firms in most other regions. Hence, they rely more on external technological resources available locally and may thus be more locked into the knowledge base provided by SINTEF and NTNU.

A third type of motive is labelled Capacity. Certain firms use the institutes due to the lack of own capacity both in general and in particularly busy periods. For these firms, the institutes constitute a capacity buffer that is available when the employees of the firm itself are too busy with other tasks or if the firm can not or will not develop internal R\&D capabilities. Finally, the statement "lack of competencies in the firm” emerges as a separate factor in this analysis. This is highlighted by a few firms which seem to have little in common.

We investigated possible differences between large and small firms in the answers to the above questions but found no significant differences. There were also few industry differences (unfortunately we do not have this information for all companies). Oil and gas companies score significantly higher (than firms in other industries) on the $R \& D$ motivation index, and "traditional manufacturing firms" score significantly higher on the Accessible index. Due to space limitations, we do not show these indexes here.

\section{The importance of $R \& D$ in research institutes to firms}

A factor analysis on the importance for firms of R\&D purchased from research institutes yields three different dimensions (0). The first is called Process, referring to firms which emphasise the importance of research institutes for developing new or improved processes, 
for developing new work methods or tools, and for increasing quality and reliability in production.

\section{[TABLE 3 ABOUT HERE]}

Another type of firms is driven by Market considerations. The respondents agree that R\&D from institutes is important for understanding the needs of customers and for helping to enter new markets. With a strong specialisation in technology and natural science at the institutes, this factor might surprise. It may be added that there is a high correlation between the market dimension and the "accessible" factor discussed in the previous table. In other words, the companies which only have knowledge about Norwegian research institutes are also the ones which rely on the institutes for help with market development and understanding user needs. The last dimension from the analysis of institute services is called Product. These firms emphasise that institutes are important to developing new or improved products and new materials. There are no statistically significant differences between industries and companies of different size in this set of questions, except that food companies are a little bit more likely to fall into the process dimension and electric/electronics firms less likely to do so.

Our data set contains information on the motivations of firms to engage in R\&D collaboration generally without limiting the focus to research institutes. More than 65 percent of the firms indicate that participation in networks to obtain up-dated knowledge is "rather" or "very" important. For firms with less than one hundred employees the share is significantly higher, suggesting that smaller firms may rely even more on outside sources of knowledge than the 
larger ones do. Another important motivation is access to applied R\&D results, highlighted by more than 60 percent of the firms and in particular the large ones. Finally, access to R\&D skills is important to 79 percent of the firms.

\section{The experiences and opinions of firms regarding institutes}

In 0 we show the results of a factor analysis run on questions related more broadly to the experiences respondents have with research institutes. They were asked to agree or disagree to a series of items pertaining to the institutes and collaboration with them. Here, we have included all firms which answered the question, regardless of whether they used the institutes in the most recent year or not. 122 firms responded, considerably more than the 99 firms from the survey that actually had purchased services from research institutes in 2000. This suggests that more than the present users have experience from collaboration with research institutes or know them from earlier contacts. A more descriptive account of the response distributions is found in Table 5 .

[TABLE 4 ABOUT HERE]

There are two dimensions in this set of questions, distinguishing between firms with positive experiences and perceptions and firms with negative or critical ones. The positive firms agree that the institutes’ R\&D services are of high quality, and in particular they value test facilities and methods. Moreover they emphasise the importance of several network-related factors for collaboration. The negative or critical firms strongly agree that they prefer to build up their 
own core competences and to do R\&D in-house. They claim that the institutes' services are fairly expensive (quite a few of the positive ones also express this), and they disagree that the services are of high quality. Around one-third of the firms which collaborate with institutes, fall into this category. Personal acquaintances are important to many of them too. We have found no systematic differences with regards to firm size. Electric/electronics firms agree significantly more than the others that they prefer to do R\&D in-house. We do not know whether this is due to negative experiences with or lack of specialised competences in the institutes, or if there are other reasons behind this.

\section{[TABLE 5 ABOUT HERE]}

0 shows that issues such as successful former experiences, reputation and personal networks are very important for firms when using research institutes or when forming opinions about them. More than half of the respondents also argue that the price charged by research institutes for their services is too high. Many research institutes are experts in selected subfields of science and technology, possibly the only experts in Norway in some cases. However, as mentioned earlier, general funding of these institutes is relatively low, and this means that the institutes charge close to market prices for their services. The responses indicate that many firms may be unhappy about the liberalisation trend and that their demand for technology is sensitive to the costs of technology.

In order to approach the hypotheses about negative effects from a large institute sector advanced by the evaluators of the RCN, we presented a certain number of assertions about 
Norwegian research institutes to the firms participating in the survey. The assertions were the following:
A: Research institutes have unique competences
B: Research institutes have good knowledge of R\&D in industry
C: There is little capacity in research institutes to conduct projects
D: Secrecy needs prevent collaboration with research institutes
E: Research institutes lack long-term funds and do not obtain fundamental research skills
F: Research institutes absorb R\&D competent labour that industry would need
G: Research institutes prevent collaboration between firms and universities

In order to see differences in views between firms with experience from purchasing R\&D services from research institutes (users) from the others (non-users), we show the share of respondents who agree partially or totally with the assertions (Figure 3). The remaining respondents do not agree or do not have an opinion. Assertions A and B - "institutes have unique competences” and “institutes have good knowledge of R\&D in industry” - are formulated positively (for the research institutes). The others are negatively formulated, and responding firms which disagree with the assertions support research institutes on these issues. Generally, institutes are supported by the firms - that is particularly the case for firms with actual experience from using research institutes. A factor analysis shows that the firms may be divided into two groups - "positive” and “critical”. However, many firms score relatively high on both these indexes, and we continue our analysis with the single items.

\section{[FIGURE 3 ABOUT HERE]}

It should first be mentioned that all the differences between users and non-users are statistically significant ( $\mathrm{D}$ at the .05 level, $\mathrm{C}$ at the .01 level and the rest at the .001 level). For 
the three assertions C, D, and E neither users nor non-users give much support to assertions about capacity in institutes, secrecy that prevents collaboration and that the research skills in institutes are lacking. Arguably, the long-term working relations between firms and institutes indicate that there is a high degree of trust between the organisations. Firms collaborate with each other, partly through the institutes, which makes secrecy a less important issue, at least as long as the institutes do not co-operate with the main foreign competitors of Norwegian firms.

The assertions $\mathrm{F}$ and $\mathrm{G}$ are direct tests of the hypotheses of the RCN evaluators that the size of the institute sector is detrimental to Norwegian industrial R\&D (Arnold et al. 2001). Less than five percent of the 460 firms from our survey agreed with the assertion that institutes attract researchers and scientists that would be more useful to firms if they had worked there. Our sample does not represent all Norwegian firms, but the number is large enough to be of interest, particularly since the firms in the survey are among the most R\&D-intensive ones in Norway and would be the ones which could be potentially hampered by a shortage of R\&D labour.

For the second argument advanced by Arnold et al. (2001) that research institutes prevent collaboration between firms and universities - and modernisation in universities - there is even less support in our survey. Only 17 firms of 460 agreed with the assertion that the institutes impede firm-university co-operation (assertion G). International R\&D indicators can be interpreted as a support to this view. Norwegian firm-university collaboration is at about OECD-average. Since Norwegian companies are less R\&D intensive and are in less R\&D 
intensive industries than companies in most other developed countries, the industry-university collaboration intensity can therefore be seen as comparatively high in Norway

\section{Teaching and mobility issues}

Research institutes have a more complex role in the research and innovation system than simply as a supplier of knowledge and learning for industry and other users. Data from the Research Council of Norway show that close to 700 researchers in the research institutes (around 10 percent of the total workforce in the sector) were involved as supervisors for students at colleges and universities in 2002 (cf. Kaloudis \& Koch 2004). In the same year, 450 graduates who were working on a Master degree or a $\mathrm{PhD}$ were formally employed at an institute.

There is thus a somewhat blurred boundary between research institutes and the higher education system. Institutes host PhD students and are involved in both teaching and basic research activities. Moreover, the universities and state colleges have increased their ownership in geographically close institutes over the past years, increasingly seeing them as an element in their strategy to improve external linkages. In some cases it is therefore difficult to distinguish research institutes from higher education organisations.

Also as far as staff is concerned, research institutes and the higher education system are closely linked. Researchers primarily employed in the higher education system worked 42 man-years (full time equivalents) in technical-industrial research institutes in 2004 (Norges 
forskningsråd 2005). Since a typical position university employees would hold in research institutes is 20 percent, this means that more than 200 university employees formally hold an adjunct position in technical-industrial research institutes. Moreover, a volume of around 26 man-years is performed in the higher education system by researchers employed primarily in technical-industrial research institutes, suggesting that around 125 institute researchers also hold adjunct professorships. Formal staff exchanges between the two sectors are thus considerable. Working relations without such formal positions may be even higher. According to figures from NTNU (the second largest university in Norway) and SINTEF (the largest research institute, located next to NTNU), around 500 researchers worked in both organisations in 2005 (source: $\underline{w w w . n t n u . n o}$ ). This is close to 20 percent of the total combined scientific staff in the organisations, and they are involved with both collaborative research projects and teaching/supervision tasks.

A further evidence of the strong interaction of researchers in the two R\&D sectors is given by co-authorship and project organisation figures. Kaloudis and Koch (2004) show that 57 percent of the scientific publications from the technical-industrial institutes in the period 1999-2002 had at least one co-author from universities and colleges. In 2004, technicalindustrial research institutes had project-based collaborations with external organisations of a volume of almost 1,600 man-years. 26 percent of the total volume involved universities and colleges in Norway and abroad, and 63 percent involved firms (Norges forskningsråd 2005). In terms of actual project-based collaboration, the institutes appear to interact much with universities. Thus, rather than being a barrier to university-industry interaction, institutes may have a "lubrication" function in the innovation system through their strong linkages to both higher education and to firms. 
It may be important to emphasise that quite different types of beneficial effects from research institutes to firms and society at large are provided as by-products from contract research. Nerdrum (1999) found that around 30 percent of the researchers who left SINTEF in the 15year period 1974-1988 followed a project they had worked on in SINTEF to take employment in the firm or organisation contracting the project. An overwhelming majority of these achieved professional "success” in their subsequent careers, suggesting both that they are valuable and skilful workers and that their training at SINTEF constituted a productive and industry-relevant type of human capital. This also means that technical-industrial research institutes provide a pool of skilled specialised labour to industry which constitutes a valuable by-product next to the R\&D services that industry purchases from the institutes and which presumably constituted the primary reason for the research project contract.

Stenstadvold (1996) stated that SINTEF had a strategy and culture which favoured transfer of researchers to industry, and considered that as part of the implicit contract the institute had with Government in exchange for basic funding. Broch et al. (2002) showed that the mobility of researchers was around 7 percent per year from the natural science and technology institutes to the business sector. If all these researchers remain in industry, we will find that half the staff of researchers in these research institutes will have moved to the business sector after seven years. Of course, many of these do not stay in firms, but move on to other types of employment and some even back to institutes after a period of time. Still, knowledge transfers and spillovers through personnel movements from research institutes may contribute decisively to the dynamics of geographical and sectoral innovation systems. 
In 0 we show the flows of incoming mobility from business sector to research institutes. Stenstadvold (1994) used records from SINTEF every fifth year from 1965 to 1990 and claimed that outgoing mobility was always much more important than incoming mobility. Stenstadvold was during the general director of SINTEF for more than 30 years and the argues that SINTEF always had a policy of attracting researchers with experience from firms, but that relatively few such researchers were willing to take employment there. This may be due to relatively low wages in SINTEF or to more attracting working conditions generally in firms. Although net flows to institutes from industry are generally positive, the incoming mobility to institutes from industry is far from negligible. Stenstadvold's observation that few industrial researchers were attracted to the institute sector may therefore no longer be true. We see that the mobility has decreased since the late 1990s but seems to be rising again in recent years. Economic slowdown and few opportunities for industrial employment around the turn of the millennium (there was e.g. a high unemployment rate for Master degree engineers in 2001 and 2002) is probably an important explanation for the decrease in mobility. This also indicates how mobility between private and public R\&D organisations is related to business cycles.

\section{[TABLE 6 ABOUT HERE]}

In the figure below, incoming and outgoing researcher flows are shown as shares by researcher man-years between the technical-industrial research institutes and industry. As mentioned, outgoing flows from technical-industrial research institutes to business are generally substantially higher than the incoming flows, except for the years 2002-2004. The figures suggest that outgoing mobility may be sensitive to demand for research personnel in industry, and from this perspective research institutes constitute a pool of skilled labour for 
firms. The incoming flows from business to technical-industrial institutes depend upon business cycles to a lesser extent.

\section{[FIGURE 4 ABOUT HERE]}

\section{Concluding remarks}

In this paper we have examined the technical-industrial research institutes, which form an important part of the research institute sector in Norway. Our empirical evidence suggests that these institutes are valuable to the innovation activity in the country. The institutes fulfil many important roles, including delivering research results and research-based services and providing valuable networks around and between firms, the higher education system and other actors in the knowledge system. A substantial amount of small services are provided by research institutes to business partners, spanning from small courses to advising and connecting business representatives. These services are not normally classified as R\&D, but are provided by research staff and research organisations and can be considered as important by-products and complementary services to $R \& D$ conducted in institutes.

By using a survey among a large number of “users” and "non-users” of research-based services from technical-industrial institutes, we show that the institutes are perceived to possess "unique” competencies and hold high quality. A predominant reason to why firms use research institutes is that they lack the skills, the R\&D capacity, equipment and methodology to conduct R\&D projects in-house. Research institutes therefore constitute an important contribution to firms in their search for innovation. However, their services are generally considered expensive. This could be due to a relatively modest contribution of public funds to 
the research institutes (underlined e.g. by Kaloudis and Koch 2004), leading them to charge “market consultancy” prices. However, many of the institutes have a strong market position and nearly operate in a monopoly situation, at least nationally.

With the data analysed in this paper, we may point to three particular roles of the technicalindustrial research institutes in Norway. First, the institutes obviously represent a learning partner to the firms. Learning happens primarily through collaborative projects - sometimes with the institutes in charge within public programmes, in other cases (probably most often) with the firm(s) in charge. Several of the projects are oriented at learning per se as they imply institute personnel teaching their colleagues in industry.

Second, the institutes contribute to increasing absorptive capacity or to overcoming problems of low absorptive capacity. We see basically two mechanisms through which this happens. One is through the numerous projects and personal contacts established between industry and institute staff - which seem to be quite stable over time. The other is the relatively high staff turnover in the institutes, i.e. personnel leave to work in industry (or elsewhere), often following their projects and bringing their expertise into the user organisation. We show that 2-10 percent of institute staff move to take employment in industry per year. In comparison, staff mobility from Norwegian universities to other sectors is tremendously low - 1 percent per year between 1991-2001 according to Nerdrum and Sarpebakken (2006). Both these mechanisms may help firms adopt new knowledge and technologies and/or to define problems and actively seek for solutions. 
Third, the research institutes have a lubrication or intermediation role in the research and innovation system. They have close relations to higher education, including personnel in adjunct and ad-hoc positions, joint laboratories and joint projects with and without industry involvement. This probably means that the institutes partly act as a buffer zone between universities and industry. Such a buffer can be seen as negative if it prevents universityindustry interaction. This does not seem to be the case as industry funding of university $R \& D$ is not lower in Norway than in other countries (Gulbrandsen and Nerdrum 2007b), and the firms themselves oppose this claim. On the contrary, having a buffer between universities and industry may actually have a beneficial effect. Recent developments at the research frontier are quickly communicated to the firms by their regular partners in institutes in a language closer to their day-to-day operations. Universities are on the other hand informed about technological developments and new ideas with basic research relevance, but may at the same time be shielded from the most mundane requests. In this manner, institutes act as a flexible “add-on” for the universities without playing a strict intermediation role in a linear relationship. We have furthermore seen that the companies use institutes to increase their capacity for R\&D, meaning that the institutes may constitute increased flexibility for industry as well. It could perhaps be said that the research institutes act as a flexible repository in the national innovation system. These issues deserve further investigation, as research institutes in general are much less studied than research units in the higher education sector. 


\section{References}

Arnold, Eric, Stefan Kuhlmann and Barend van der Meulen, 2001, A Singular Council. Evaluation of the Research Council of Norway, Technopolis, Brigthon.

Arrow, Kenneth, 1962, "Economic Welfare and the Allocation of Resources for Invention,”, in The Rate and Direction of Inventive Activity, Princeton university Press, pp.609625, reprinted in Nathan Rosenberg, ed., 1971, The economics of technological change, Penguin Books Ltd., pp. 64-181.

Broch, Marianne, Magnus Gulbrandsen, Lars Nerdrum and Morten Staude, 2001, Forskningsinstituttene og næringslivet. Delrapport 1: aktørene i samspillet. Oslo: NIFU, Skriftserie 30/2001.

Broch, Marianne, Morten Staude, and Svein Olav Nås, 2002, Hvem er forskningsinstituttenes næringslivskunder?, Delrapport 2, STEP-rapport R-08, oktober.

Brofoss, Karl Erik and Lars Nerdrum, 2002, ”Forskningsinstituttene og næringslivet. Delrapport 3: Bedriftenes kjøp av FoU fra instituttene”, NIFU Skriftserie 23/2002.

Brofoss, Karl Erik, Magnus Gulbrandsen, Lars Nerdrum and Svein Olav Nås, 2002, "Forskningsinstituttenes betydning for FoU i næringslivet - Syntese og utfordringer", NIFU Skriftserie 26/2002.

Brofoss, Karl Erik and Gunnar Sivertsen, 2004, De samfunnsvitenskapelige instituttene, NIFU STEP skriftserie nr. 3/2004, Oslo.

Brofoss, Karl Erik and Stig Slipersæter, 2004, Forskningsinstituttenes rammebetingelser for internasjonal konkurranse, NIFU STEP skriftserie nr. 19/2004, Oslo.

Bush, Vannevar, 1945, Science - The Endless Frontier. A report to the President on a program for postwar scientific research, National Science Foundation, Washington D.C.

Cohen, Wesley M. and Daniel A. Levinthal, 1989, "Innovation and learning: the two faces of R\&D”, Economic Journal, vol.99, no. 397, September, pp.569-596

Crow, M. and B. Bozeman (1987), "R\&D laboratory classification and public policy: the effects of environmental context on laboratory behavior,” Research Policy, vol.16, pp.229-258.

David, Paul A and Dominique Foray, 1995, “Accessing and Expanding the Science and Technology Base”, STI nr. 16, OECD, pages 13-68.

Etzkowitz, Henry and Loet Leydesdorff, (1997, Universities and the Global Knowledge Economy: A Triple Helix of University-Industry-Government Relations, Pinter/Cassel, London.

Etzkowitz, Henry and Loet Leydesdorff, 2000, “The Dynamics of Innovation: From National Systems and 'Mode 2' to a Triple Helix of University-Industry-Government Relations,” Research Policy vol.29, pp.109-123.

Gibbons, M., C. Limoges, H. Nowotny, S. Schwartzman, P. Scott and M. Trow, 1994, The New Production of Knowledge. The Dynamics of Science and Research in Contemporary Societies, Sage Publications, London. 
Gulbrandsen, Magnus and Lars Nerdrum, 2007a, "Public R\&D and industrial innovation in Norway - a historical perspective”, TIK Working Paper on Innovation Studies no. 20070602

Gulbrandsen, Magnus and Lars Nerdrum, 2007b, “University-industry relations in Norway”, TIK Working Papers on Innovation Studies no. 20070613.

Kaloudis, Aris and Per Koch, 2004, De ncringsrettede forskningsinstituttenes rolle i det fremtidige innovasjonssystemet, NIFU STEP Rapport 4/2004, Oslo.

Larédo, Philippe, 2003, “Six major challenges facing public intervention in higher education, science, technology and innovation,” Science and Public Policy, vol.32, pp.

Larédo, Philippe and Philippe Mustar (eds.), 2001, Research and Innovation Policies in the New Global Economy. An International Comparative Analysis, Cheltenham: Edward Elgar.

Mathisen, Werner C., 1989, Mellom akademia og marked. Styring av forskning i instituttsektoren. Oslo: NAVFs utredningsinstitutt, Melding 1989:2.

Ministry of Education, Research and Church Affairs, 1999, Forskning ved et tidsskille, St.meld.nr.39, 1998-1999, White Paper, $11^{\text {th }}$ June.

Ministry of Education and Research, 2005, Vilje til forskning, St.meld.nr. 20, 2004-2005, White Paper, $18^{\text {th }}$ March.

Moe, Johannes, 1990, “Bør den norske instituttlinje avvikles? De teknisk-industrielle institutter på 1990-tallet” in Hans Skoie og Einar Ødegård (eds.) De tekniskindustrielle forskningsinstitutter i 1990-årene, NAVFs utredningsinstitutt, Rapport 5/90, Oslo.

Nelson, Richard R., 1959, “The simple economics of basic scientific research”, The Journal of Political Economy, 67:297-

Nelson, Richard R., 1993, “A retrospective.” In Nelson, Richard R. (ed.), 1993, National Innovation Systems: A Comparative Analysis. New York: Oxford University Press, pp. 505-523.

Nelson, Richard R. and Nathan Rosenberg. 1993, “Technical innovation and national systems.” In Nelson, Richard R. (ed.), 1993, National Innovation Systems: A Comparative Analysis. New York: Oxford University Press, pp. 3-21.

Norges forskningsråd, 2006, Nytt basisfinansieringssystem for instituttsektoren. Forslag fra Norges forskningsråd, oktober 2006

Nerdrum, Lars, 1999, The Economics of Human Capital: A Theoretical Analysis Illustrated Empirically by Norwegian Data, Scandinavian University Press, Oslo

Nerdrum, Lars and Bo Sarpebakken, 2006, "Mobility of foreign researchers in Norway”, Science and Public Policy, vol. 33 (3), April, pp. 217 - 229.

Norges forskningsråd, 2005, Årsrapport 2004. Forskningsinstituttene. Delrapport for tekniskindustrielle institutter, Oslo, juni.

NOU 1981:30A, ”Forskning, teknisk utvikling og industriell innovasjon” (Thulin Commission).

Nowotny, Helga, P. Scott and M. Gibbons, 2001, Re-thinking Science: Knowledge and the Public in an Age of Uncertainty, Polity Press, Cambridge. 
Research Council of Norway, 2006, Report on Science and Technology Indicators for Norway 2005.

Skoie, Hans, 1990, “Økt markedsstyring eller mer langsiktighet?” (”Increased market stearing or more long-term policy?”), in Hans Skoie and Einar Ødegård (eds.), De tekniskindustrielle forskningsinstitutter i 1990-årene, NAVFs utredningsinstitutt, Rapport 5/90, pp. 63-73.

Skoie, Hans, 2005, Norsk forskningspolitikk i etterkrigstiden. Oslo: Cappelen akademisk forlag.

Slipersæter, Stig and Kaja Wendt, 2006, ”Instituttene: Ikke så særnorske likevel”, Forskningspolitikk, 3/2006.

Slipersæter, Stig, Kaja Wendt and Bo Sarpbakken, 2003, "Instituttsektoren i et internasjonalt perspektiv belyst ved FoU-statistiske data”, NIFU skriftserie nr. 30/2003.

Smeby, Jens-Christian, 2005, ”Grunnforskning og anvendt forskning”. In Gulbrandsen, Magnus \& Jens-Christian Smeby (eds.), Forskning ved universitetene: rammebetingelser, relevans og resultater. Oslo: Cappelen akademisk forlag, pp. 127146.

Stenstadvold, Karl, 1994, Hvor ble det av forskerne etterpå? Og hva mener de i dag? En mobilitetsstudie, SINTEF rapport STF01A 94010, oktober.

Stokes, Donald E., 1997, Pasteur's Quadrant: basic science and technological innovation, Brookings institution Press, Washington D.C.

Wicken, Olav, 1992a, “Samspillet mellom militær og sivil forskning I Norge 1945-1975”, Notat 2/92, NTNF-programmet "Fremtidsrettet teknologipolitikk".

Wicken, Olav, 1994a, ”Elektronikkrevolusjonen” in Olav Wicken red., 1994, Elektronikkentreprenørene. Studier av norsk elektronikkforskning og-industri etter 1945, Ad Notam Gyldendal, Oslo, pp. 10-23.

Wiig, Ole, 1990, Forsknings- og utviklingsarbeid i Norge og andre OECD-land, Utredningsinstituttet for forskning og høyere utdanning, Oslo, Rapport 7/1990.

Wiig, Ole and Werner Christie Mathisen, 1994, Instituttsektoren - mangfold og utvikling. En studie med særlig vekt på perioden 1983-91 ("The institute sector - heterogeneity and development. A study with particular emphasis on the period 1983-91”), Utredningsinstituttet, Rapport 5/94.

Ødegård, 1990, ”Instituttsektor og regionale randsoneinstitusjoner” (Institute sector and regional border area institutions", in Hans Skoie and Einar Ødegård (eds.), De tekniskindustrielle forskningsinstitutter i 1990-årene, NAVFs utredningsinstitutt, Rapport 5/90, pp.29-35. 
Table1: Industrial customers and projects above $€ 1,250$ at 41 Norwegian research institutes in 2000.

\begin{tabular}{|l|r|c|c|}
\hline Institute group (N) & $\begin{array}{l}\text { No. ind. } \\
\text { Projects }\end{array}$ & Mean proj.size(€) & €/customer \\
\hline Primary (10) & 466 & 39826 & 55804 \\
\hline Social Sciences (14) & 240 & 24080 & 40497 \\
\hline Environment and dev. (5) & 299 & 21993 & 32186 \\
\hline Science \&Tech (12) & 2873 & 38755 & 71352 \\
\hline All (41) & 3878 & 31961 & 52248 \\
\hline
\end{tabular}

Source: Data from Broch et al. (2001)

Table2: Reasons among firms for purchases of R\&D services from Norwegian research institutes, factor analysis.

\begin{tabular}{|l|r|r|r|r|}
\hline Rotated Component Matrix & \multicolumn{3}{|c|}{ Component } \\
\hline & $\begin{array}{r}\text { R\&D } \\
\text { motivation }\end{array}$ & Accessible & Capacity & $\begin{array}{c}\text { Lack of } \\
\text { competence }\end{array}$ \\
\hline Lack of own capacity generally &, 007 &, 106 &, $\mathbf{8 7 8}$ &, 184 \\
Lack of capacity in particularly busy periods &,- 001 &, 367 &, 740 &,- 159 \\
Lack of competencies in the firm &, 064 &,- 012 &, 111 &, 870 \\
Lack of equipment/testing facilities &, 070 &, 608 &, 159 &,- 028 \\
Strategy to increase the firm's R\&D competences &, 777 &, 092 &,- 081 &,- 064 \\
Obtain participation in competence networks &, $\mathbf{8 3 9}$ &, 222 &,- 084 &, 089 \\
Access to public R\&D funding &, $\mathbf{4 6 7}$ &,- 154 &, 261 &,- 338 \\
Increase the quality of in-house R\&D &, 658 &,- 158 &, 423 &, 275 \\
Geographical proximity is important &,- 021 &, 630 &, 270 &, 002 \\
Only knowledgeable about Norwegian institutes &,- 089 &, 658 &,- 095 &, 460 \\
Personal contacts in the institute(s) &, 462 &, 629 &,- 039 &,- 063 \\
\hline Percentage of variance explained & 19.9 & 16.8 & 15.5 & 11.2 \\
Cumulative percentage & 19.9 & 36.7 & 52.2 & 63.4 \\
\hline
\end{tabular}

Extraction Method: Principal Component Analysis. Rotation Method: Varimax with Kaiser Normalization. Rotation converged in 7 iterations.

Table3: How important is R\&D purchased from Norwegian research institutes for...? Factor analysis.

\begin{tabular}{|l|r|r|r|}
\hline Rotated Component Matrix & \multicolumn{3}{|c|}{ Component } \\
\hline Development of new or improved products & \multicolumn{1}{|c|}{ Process } & \multicolumn{1}{|c|}{ Market } &, 781 \\
Development of new or improved processes &,- 037 &, 384 &, 230 \\
Development of new materials &, $\mathbf{8 1 5}$ &, 080 &, $\mathbf{7 0 2}$ \\
Development of new work methods/tools &, 274 &, 180 &, 019 \\
Improved quality and reliability in production &, $\mathbf{8 2 1}$ &, 323 &, 071 \\
Improved understanding of customer needs &, 798 &, 363 &, 060 \\
Obtaining/entering new markets &, 306 &, $\mathbf{8 1 1}$ &, 052 \\
\hline Percentage of variance explained &, 189 & 24.8 & 18.8 \\
Cumulative percentage & 31.2 & 56.0 & 74.8 \\
\hline
\end{tabular}

Extraction Method: Principal Component Analysis. Rotation Method: Varimax with Kaiser Normalization. Rotation converged in 6 iterations. 
Table4: Firms' experiences with and opinions of the research institutes, factor analysis.

\begin{tabular}{|l|r|r|}
\hline Rotated Component Matrix & \multicolumn{2}{|c|}{ Component } \\
\hline The institutes' R\&D services are fairly expensive & Positive & Negative \\
The institutes' R\&D services are of high quality &, $\mathbf{6 2 5}$ \\
Personal acquaintances are important &, $\mathbf{5 0 7}$ &,$- \mathbf{5 3 1}$ \\
Good former experience is important &, $\mathbf{6 8 8}$ &, 130 \\
The institutes' reputation is important &, $\mathbf{8 3 1}$ &, 142 \\
The institutes have valuable test facilities and methods &, $\mathbf{7 9 9}$ &,- 076 \\
The firm needs its own core competencies and prefers to &, $\mathbf{5 2 3}$ &,- 342 \\
do R\&D in-house &,- 057 &, $\mathbf{7 8 6}$ \\
Percentage of variance explained & 34.0 & 20.7 \\
Cumulative percentage & 34.0 & 54.7 \\
\hline
\end{tabular}

Extraction Method: Principal Component Analysis. Rotation Method: Varimax with Kaiser Normalization. Rotation converged in 3 iterations.

Table5: To what extent do respondents agree with the following assertions about the research institutes and their activity? Frequencies of response.

\begin{tabular}{lrrr}
\hline & Agree & Disagree & No opinion \\
\hline Experience from earlier collaboration is important & $88 \%$ & $2 \%$ & $11 \%$ \\
Rumours about the institutes are important & $77 \%$ & $5 \%$ & $18 \%$ \\
Personal acquaintances are important & $69 \%$ & $12 \%$ & $20 \%$ \\
The institutes have high quality & $64 \%$ & $8 \%$ & $28 \%$ \\
The institutes possess valuable test sites and test methods & $64 \%$ & $9 \%$ & $27 \%$ \\
The institutes are relatively expensive & $56 \%$ & $6 \%$ & $39 \%$ \\
The firm needs own R\&D and prefers to conduct R\&D itself & $40 \%$ & $32 \%$ & $29 \%$ \\
\hline
\end{tabular}

Table6: Outgoing and incoming researcher mobility between technical-industrial research institutes and business sector. Absolute numbers. 1997-2005

\begin{tabular}{l|ccccccccc}
\hline & 1997 & 1998 & 1999 & 2000 & 2001 & 2002 & 2003 & 2004 & 2005 \\
\hline Outgoing mobility & 195 & 167 & 105 & 171 & 107 & 81 & 38 & 53 & 82 \\
Incoming mobility & 60 & 95 & 45 & 55 & 81 & 86 & 56 & 56 & 55 \\
\hline Net inflows & 135 & 72 & 60 & 116 & 26 & -5 & -18 & -3 & 27 \\
\hline
\end{tabular}

Notes: FFI (The Defence Research Institute) is not included in the table due to missing and incomplete data. Shares do not always sum up due to rounding errors. Source: Key figures on the institute sector, NIFU STEP. 


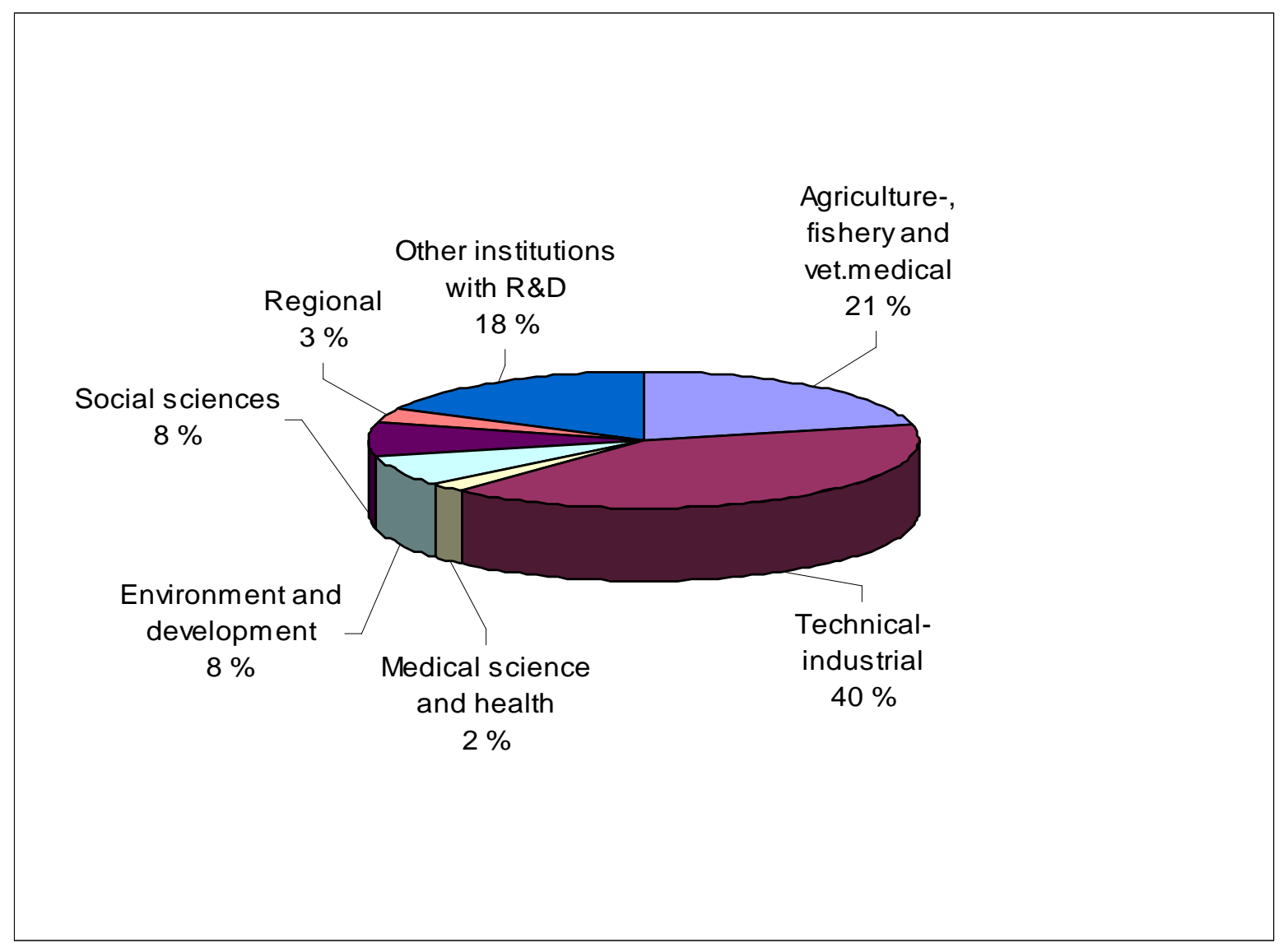

Figure 1: Total R\&D expenditure in the institute sector in 2005 by group of institutes and field of research, 110 institutes with R\&D activities in Norway. (Percent) Source: Research Council of Norway 2006.

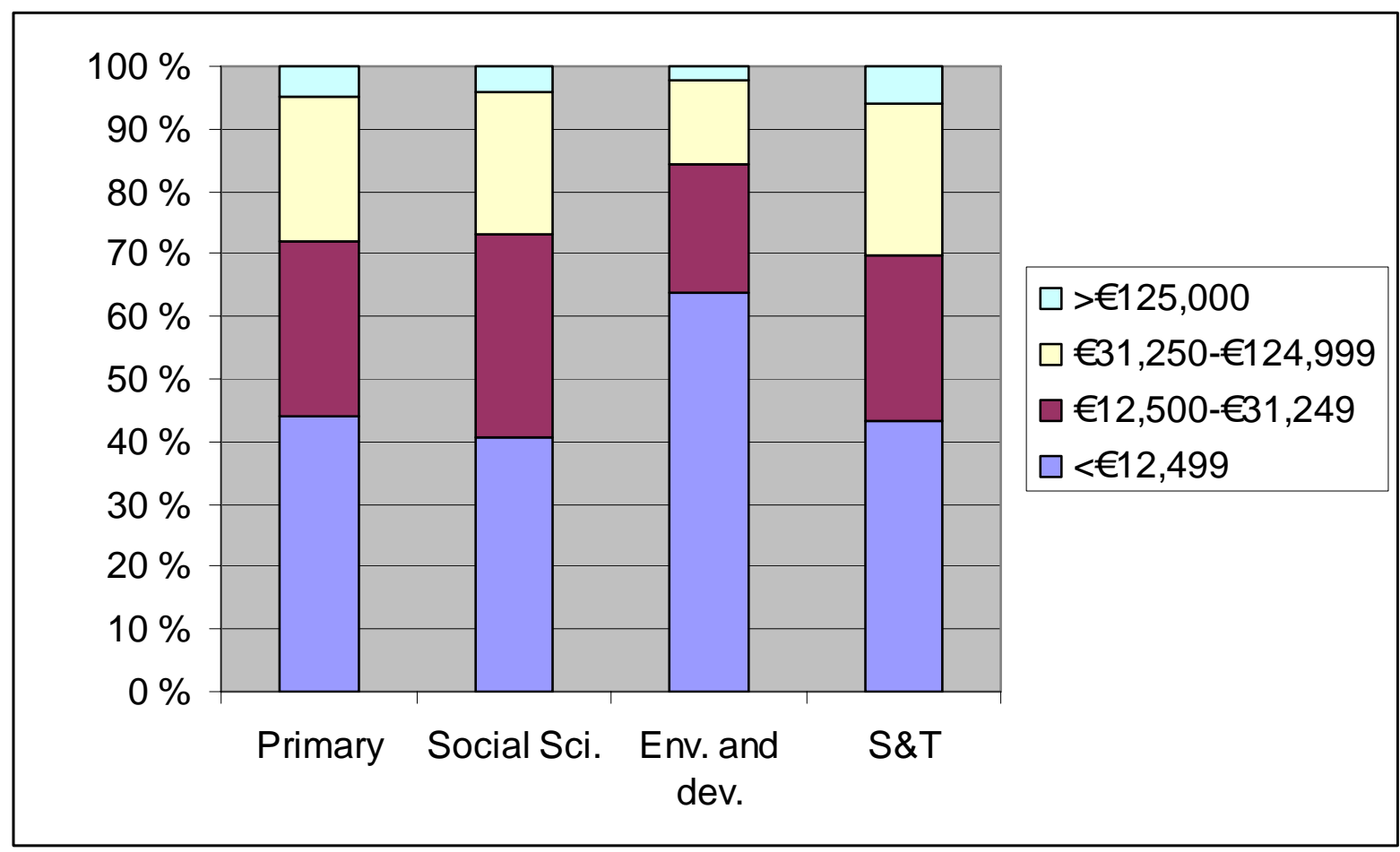

Figure 2: Project sizes above $€ 1,250$ at the 41 most industry-relevant research institutes. (Number of industrial projects in 2000) Source: Broch et al. (2001). 


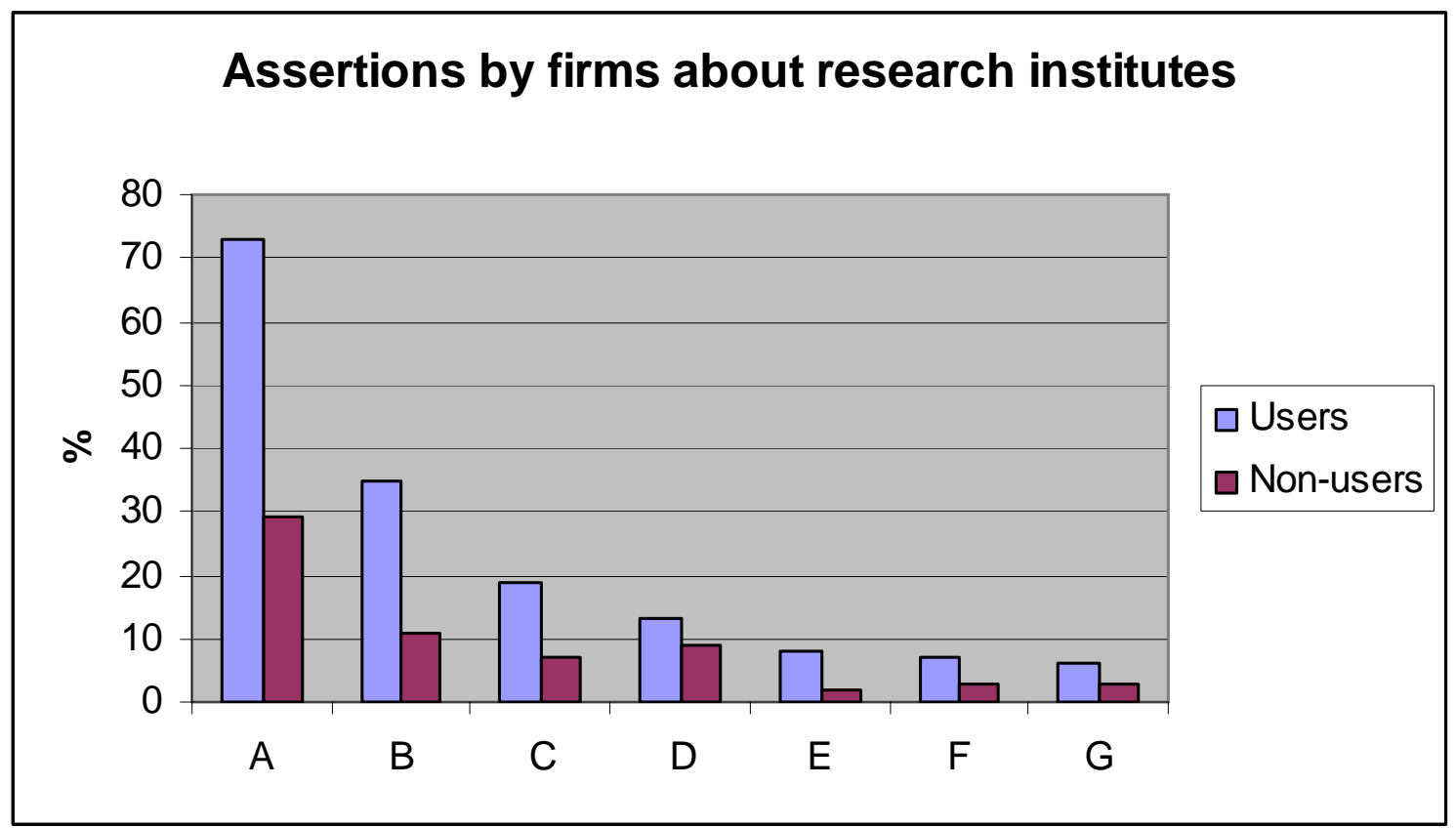

Figure 3: Users $(\mathrm{N}=127)$ and non-users $(\mathrm{N}=333)$ who agree totally or partially with a number of assertions about Norwegian research institutes. (Shares)

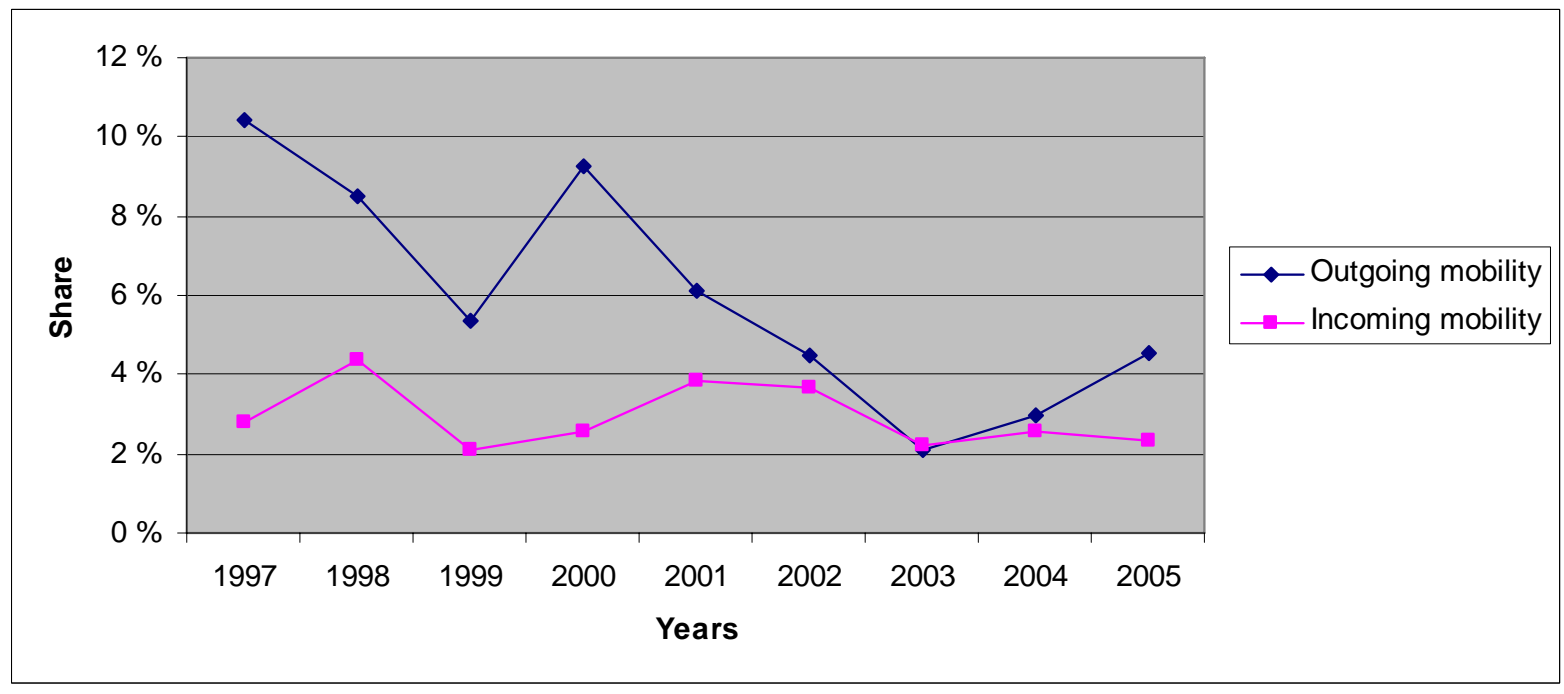

Figure 4: Outgoing and incoming mobility between technical-industrial research institutes to business sector. (Shares of researcher-years 1997-200) Source: key figures on research institutes, NIFU STEP. 